\title{
（5）高精細液晶表示技術の現状と将来性 \\ Current Status and Future Possibility of High-Resolution Liquid Crystal Display Technology
}

\author{
セイコーエプソン(侏)研究開発本部大島弘之
}

液晶表示技術の進展はめざましく多くの方式が開発されているが、放射線像出力デバイスとしては 解像度 (画素数) や階調表示性能の点から、アクティブマトリクス方式が最も有望であろう。本方式 は、高度な半導体技術を取り込み、各画素に集積したトランジスタやダイオードを介して液晶を駆動 する方式であり、製造の困難さを伴うものの、ディスプレイの解像度や階調、コントラストなどの点 で高い画筫を得ることができる。本方式を用いた液晶ディスプレイは、対角 2 インチの小型ポケット テレビ用として 1984 年に初めて実用化され、現在、対角 8〜10 インチ、画素数640（カラー 表示の場合は× 3 ）×480、16 階調表示のパソコン用ディスプレイの商品化が始まったところで ある。試作レベルでは、H D T V用やEWS（エンジニアリングワークステーション）用として対角 15 １7 インチ、画素数 1000 ( × 3 ) × 1000 程度、256階調の液晶ディスプレイも報告 されている。一方、これら直視型ディスプレイのみならず、微細な画素を高密度に集積した小さい液 晶ライトバルブを拡大投射するプロジェクションディスプレイの発展も著しい。既に対角 3.7 イ チの小型うイトバルブに1440×1024画素を集積したプロジェクタも試作されている。

更なる可能性を秘め大きな期待を担う液晶ディスプレイではあるが、コスト低減・大画面化・広視 角化など解決すべき課題も多い。中でもコストは大きな課題であり、対角 10 インチ、画䒺数 640 (×3) ×480で5万円という業界共通の目標達成にはまだ数年を要するであろう。大面積（例元 ば対角 20 インチ）に数百万個に及ぶ画素数分のトランジスタを均一に無欠骝で製造する困難も想像 に難くない。視角によって画質、特に階調表示性能が変化する現象は液晶の本質的課題である。この ような課題を最も短距離で解決する方法は投射型ディスプレイであるが、理想的な放射線像出力デバ イスとは言い難い。最終的な直視型ディスプレイの実用化にはまだ年数が必要であるが、電磁波障害 がなく人間に優しい省エネルギー・省スペースの電子ディスプレイを目指して、液晶表示技術は着実 に進歩して行くものと期待される。 